\title{
Superoxide dismutase and catalase in Photobacterium damselae subsp. piscicida and their roles in resistance to reactive oxygen species
}

\author{
Andrew C. Barnes, ${ }^{1}$ M. Carmen Balebona, ${ }^{1}$ Michael T. Horne ${ }^{2}$ \\ and Anthony E. Ellis ${ }^{1}$ \\ Author for correspondence: Andrew Barnes. Tel: +44 1224 295606. Fax: +44 1224295620. \\ e-mail: barnesa@marlab.ac.uk
}

\footnotetext{
1 FRS Marine Laboratory, PO Box 101, Victoria Road. Aberdeen AB11 9DB, UK

2 Aqua Health (Europe) Ltd, Enterprise House, Springkerse Business Park, Stirling FK7 7UF, UK
}

\begin{abstract}
Photobacterium damselae subsp. piscicida (formerly Pasteurella piscicida) is the causative agent of pasteurellosis or pseudotuberculosis in warm water marine fish. Enzymes which neutralize reactive oxygen species, produced during aerobic metabolism or during respiratory burst in fish macrophages, are important virulence factors in many pathogens. This study characterizes a periplasmic superoxide dismutase (SOD) and a cytoplasmic catalase in $P$. damselae. Purification and partial amino-terminal sequencing confirmed the SOD to be iron-cofactored, with a high degree of homology to other bacterial FeSODs. The SOD was common to all strains analysed in terms of type, location and activity, whilst the catalase varied in activity between strains. The catalase was constitutively expressed, but the SOD appeared to be repressed under low oxygen conditions. In spite of the presence of a periplasmic SOD, P. damselae was susceptible to killing by exogenous superoxide anion generated in a cellfree system. Addition of exogenous SOD to this system did not abolish the bactericidal effect; however, addition of catalase was protective. These results suggest that lack of periplasmic catalase may be implicated in susceptiblity to killing by reactive oxygen species.
\end{abstract}

Keywords: Photobacterium damselae subsp. piscicida, superoxide dismutase, catalase, antioxidant defences, periplasmic FeSOD

\section{INTRODUCTION}

Photobacterium damselae subsp. piscicida (formerly Pasteurella piscicida, Gaulthier et al., 1995), the causative agent of pseudotuberculosis or pasteurellosis, is responsible for extensive losses in aquaculture. Pasteurellosis has been reported in wild and cultured marine fish species in Japan (Kubota et al., 1970; Ueki et al., 1990), USA (Sniezsko et al., 1964; Hawke et al., 1987) and more recently in Europe, mainly affecting sea bass and gilthead sea bream (Toranzo et al., 1991; Balebona et al., 1992).

Studies on the phenotypic and serological characteristics

Abbreviations: GS, glutamine synthetase; $M D H$, malate dehydrogenase; SOD, superoxide dismutase.

The EBI/SWISS-PROT accession number for the amino acid sequence reported in this paper is $P 81527$. of this pathogen have demonstrated that $P$. damselae constitutes a highly homogeneous taxon (Magariños $e t$ al., 1992). Moreover, extracellular products and iron have been implicated in the pathogenesis of this disease in fish (Magariños et al., 1992, 1994). However, despite these studies, information on the pathogenesis of the infection and interaction with phagocytes are still scarce and in some cases contradictory results have been reported (Noya et al., 1995a; Skarmeta et al., 1995).

Cell metabolism of oxygen produces reactive species toxic for many micro-organisms (Welch et al., 1979; Bandín et al., 1993; Barnes et al., 1996; Hardie et al., 1996). This toxicity is mediated by products resulting from the univalent reduction of molecular oxygen, including the superoxide radical $\left(\mathrm{O}_{2}{ }^{-}\right)$, hydrogen peroxide $\left(\mathrm{H}_{2} \mathrm{O}_{2}\right)$ and the hydroxyl radical $\left(\mathrm{OH}^{\cdot}\right)$ (Fridovich, 1995; Keyer et al., 1995; Hampton et al., 1996). Additionally, infectious organisms may encounter re- 
active oxygen species from respiratory burst activity of phagocytic cells. Consequently, enzymes involved in antioxidant defences in pathogens have been associated with microbial virulence. Among these enzymes, superoxide dismutases (SODs), a family of three metalloenzymes, are capable of disproportionating $\mathrm{O}_{2}{ }^{-}$, the first reactive oxygen species formed in the metabolic reduction of oxygen, into $\mathrm{H}_{2} \mathrm{O}_{2}$. Subsequently, the presence of catalase activity decomposes $\mathrm{H}_{2} \mathrm{O}_{2}$ into oxygen and water.

Both SOD and catalase have been reported to protect certain pathogenic bacteria during the respiratory burst following phagocytosis. Thus, SODs of Shigella flexneri (Franzon et al., 1990), Listeria monocytogenes (Welch et al., 1979) and the fish pathogen Aeromonas salmonicida (Barnes et al., 1996) have been reported to reduce the killing efficacy of the oxygen radicals, whereas catalase activity is thought to protect Staphylococcus aureus (Mandell, 1975). However, the protective role of these enzyme activities is variable and catalase appears to make a limited contribution to virulence in Shigella flexneri (Franzon et al., 1990) and Salmonella typhimurium (Tsolis $e$ al., 1995). Thus, the contribution of a particular detoxifying enzyme for reactive oxygen intermediates in protection against phagocytic killing mechanisms may vary with the organism and the model system studied. Studies on survival of Nocardia spp. in polymorphonuclear leukocytes have demonstrated that bactericidal activity at early time points is due to oxidative metabolism, whereas killing after $3 \mathrm{~h}$ was achieved by both oxidative and non-oxidative mechanisms (Beaman \& Beaman, 1984). Resistance to early killing in phagocytes is, therefore, more likely to be mediated by enzymes which provide protection against oxygen-dependent microbicidal mechanisms.

Intracellular location of these enzymes has been reported to have an important role in the ability of bacteria to survive oxidative stress (Gregory et al., 1973). Thus, a periplasmic location could contribute to the elimination of reactive oxygen species from external sources such as phagocytes, while a cytoplasmic location may be more relevant in dealing with radicals generated during cellular metabolism.

Contradictory results have been reported on the survival of $P$. damselae in fish macrophages. In vitro studies have shown that this pathogen is killed by fish macrophages (Skarmeta et al., 1995). However, histological studies of infected fish have observed intact bacteria inside macrophages, suggesting that they could survive the phagocyte respiratory burst (Noya et al., 1995a). Information on the role of SOD and catalase activity in this fish pathogen could contribute to the understanding of the interactions between phagocytes and $P$. damselae cells.

To our knowledge, no previous studies on the presence, type and location of SOD and catalase in P. damselae have been carried out. To provide such information and to determine the role of these enzymes in the possible protection of the bacterium against oxidative stress are the aims of this communication.

\section{METHODS}

Bacterial strains. Six strains of $P$. damselae (MT1376, MT1377, MT1378, MT1379, MT1380 and MT1415), originally isolated from clinical outbreaks of pasteurellosis affecting gilthead sea bream in Greece and Italy, or yellowtail in Japan, were obtained from the Marine Laboratory, Aberdeen, collection. Another two strains of $P$. damselae from the American Type Culture Collection, Manassas, VA, USA (ATCC 17911 and ATCC 29690) were also included in this study. Bacteria were stored at $-80^{\circ} \mathrm{C}$ in tryptic soy broth (Oxoid) supplemented with $2 \% \mathrm{NaCl}$ (TSB-2) and $20 \%$ glycerol. Bacteria were cultured on tryptic soy agar (Oxoid) containing $2 \% \mathrm{NaCl}$ (TSA-2) and incubated at $22^{\circ} \mathrm{C}$ for $48 \mathrm{~h}$. One colony was used to inoculate $10 \mathrm{ml}$ broths which were incubated with shaking overnight at $22^{\circ} \mathrm{C}$. Aliquots $(25 \mu \mathrm{l})$ of these cultures were used to inoculate $250 \mathrm{ml}$ flasks containing $100 \mathrm{ml} \mathrm{TSB}-2$ and they were incubated at $22^{\circ} \mathrm{C}$ in a rotary shaker (150 r.p.m.).

Preparation of crude extracts. Cells grown as described above were harvested by centrifugation at $3500 \mathrm{~g}$ for $15 \mathrm{~min}$ at $4{ }^{\circ} \mathrm{C}$ and washed twice in $25 \mathrm{mM}$ potassium phosphate buffer, $1 \mathrm{mM}$ disodium EDTA, pH 7.2, 0.5 mM PMSF (Sigma) and finally resuspended in $2 \mathrm{ml}$ of the same solution. Suspensions were sonicated on ice at $8 \mu \mathrm{m}$ for $90 \mathrm{~s}(6 \times 15 \mathrm{~s}$ with $30 \mathrm{~s}$ cooling between bursts) and finally centrifuged at $16000 \mathrm{~g}$ for $45 \mathrm{~min}$ at $4{ }^{\circ} \mathrm{C}$. Supernatants were assayed for the presence of SOD and catalase on acrylamide gels. Protein content was determined by using the BCA assay (Pierce $\&$ Warriner).

Partial purification of SOD. Frozen cell paste ( $1 \mathrm{~g}$ wet $\mathrm{wt}$ ) was resuspended in $2 \mathrm{ml} 25 \mathrm{mM}$ potassium phosphate buffer, $1 \mathrm{mM}$ disodium EDTA, $\mathrm{pH} 7 \cdot 2$, containing $0.5 \mathrm{mM}$ PMSF. Cell suspensions were sonicated as described above and centrifuged at $100000 \mathrm{~g}$ for $1 \mathrm{~h}$ at $4^{\circ} \mathrm{C}$.

Supernatant was filtered $(0.22 \mu \mathrm{m})$ and $200 \mu \mathrm{l}$ aliquots were applied to a Superose $6 \mathrm{HR} 10 / 30$ column connected to an FPLC system (Pharmacia). Chromatography was performed in $50 \mathrm{mM}$ Tris/ $\mathrm{HCl}, \mathrm{pH} 7 \cdot 7$, containing $50 \mathrm{mM} \mathrm{NaCl}$ and $0.05 \%$ sodium azide at a flow rate of $0.5 \mathrm{ml} \mathrm{min}^{-1}$. Fractions $(1 \mathrm{ml})$ containing SOD activity from three replicate runs were pooled and applied to a Mono-Q HR5/5 anion exchange column and eluted at $1 \mathrm{ml} \mathrm{min}{ }^{-1}$ on a linear gradient of $50-400 \mathrm{mM} \mathrm{NaCl}$ in $50 \mathrm{mM}$ Tris/ $\mathrm{HCl}, \mathrm{pH} 7 \cdot 7$, over $40 \mathrm{ml}$. SOD activity was detected in three fractions; however, one fraction (F26) contained most of the SOD activity and minor contamination (one major and three minor bands detected in SDS-PAGE by Aurodye; Amersham). This fraction was desalted using a fast desalt column HR10/10 (Pharmacia) and reapplied to the Mono-Q column, this time eluting over a more gradual gradient $(150-300 \mathrm{mM} \mathrm{NaCl}$ over $40 \mathrm{ml})$. Fraction 24 contained only 1 band in addition to SOD. An aliquot $(200 \mu \mathrm{l})$ of this fraction was applied to Superose 12 HR 10/30 and eluted in $50 \mathrm{mM}$ Tris/ $\mathrm{HCl}, \mathrm{pH} 7 \cdot 7$, containing $50 \mathrm{mM} \mathrm{NaCl}$ at $0.5 \mathrm{ml} \mathrm{min}^{-1}$. SOD was eluted in one peak over two $1 \mathrm{ml}$ fractions. Fraction 9 (the leading edge of the peak) contained essentially pure SOD as analysed by native and SDS-PAGE, stained with Coomassie brilliant blue, and Western blotting onto PVDF (Immobilon P, Millipore), stained with Aurodye (Amersham).

Amino-terminal sequencing. Purified SOD protein was excised from an SDS-PAGE gel and subjected to automated Edman sequencing on an Applied Biosystems model 477A pulsed-liquid sequencer, equipped with on-line PTH analysis, at the Protein Facility, Department of Molecular and Cell Biology, University of Aberdeen. 
Electrophoresis and in situ staining. Electrophoresis was performed on non-denaturing acrylamide gels using the BioRad Mini Protean II System with Tris/glycine buffer. Samples were applied to $10 \%$ bisacrylamide gels prepared with $1.5 \mathrm{M}$ Tris $/ \mathrm{HCl}, \mathrm{pH} 8$. Electrophoresis was carried out at $200 \mathrm{~V}$.

SOD activity was visualized on gels following the methodology described by Beauchamp \& Fridovich (1971). Briefly, gels were washed in distilled water, then soaked in a solution of $2.45 \mathrm{mM}$ nitro blue tetrazolium (Sigma) for $20 \mathrm{~min}$, followed by a $10 \mathrm{~min}$ incubation in a solution containing $28 \mathrm{mM}$ tetramethylethylenediamine (TEMED, Sigma), $0.028 \mathrm{mM}$ riboflavin (Sigma) and $36 \mathrm{mM}$ potassium phosphate buffer, pH 7·8. Gels were illuminated on a light box to obtain a dark background with achromatic bands corresponding to SOD activity.

Catalase activity was visualized on non-denaturing acrylamide gels following the methodology specified by Woodbury et al. (1971). After electrophoresis, gels were washed three times in distilled water for $20 \mathrm{~min}$ and soaked in a solution of $0.015 \%$ $\mathrm{H}_{2} \mathrm{O}_{2}$. Activity was then visualized by transferring the gels to a solution of $1 \%$ ferric chloride, $1 \%$ potassium ferricyanide. Regions corresponding to catalase activity were identified as yellow bands on a green background.

Intracellular location of SOD and catalase activities. Several methods were compared to obtain periplasmic extracts with low cytoplasmic contamination.

Cell suspensions. Bacterial cultures $(100 \mathrm{ml}$ broth in $250 \mathrm{ml}$ flasks) were incubated at $22^{\circ} \mathrm{C}$ until late exponential phase $(33 \mathrm{~h})$ in a rotary shaker ( 150 r.p.m.). Cells were harvested by centrifugation at $3500 \mathrm{~g}$ for $10 \mathrm{~min}$ at $4{ }^{\circ} \mathrm{C}$ and standardized turbidimetrically $\left(\mathrm{OD}_{540}=1 \cdot 0\right)$ to $1.0 \times 10^{9}$ cells $\mathrm{ml}^{-1}$. Aliquots containing $50 \mathrm{ml}$ of this cell suspension were used for spheroplast extractions.

CHAPS-lysozyme extraction. This method was developed according to a modification by Barnes et al. (1996) of the method described by Stabel et al. (1994). After centrifugation of the bacterial suspensions $(50 \mathrm{ml})$ with $10^{9}$ cells $\mathrm{ml}^{-1}$, cells were resuspended to their original concentration in $0.2 \mathrm{M}$ Tris/ $\mathrm{HCl}, \mathrm{pH} 8$, and an equal volume of $0.2 \mathrm{M}$ Tris $/ \mathrm{HCl}, \mathrm{pH} 8$, supplemented with $1.0 \mathrm{M}$ sucrose and $0.5 \%$ CHAPS was added. Lysozyme (Sigma) was added to achieve a final concentration of $100 \mu \mathrm{g} \mathrm{ml}^{-1}$ and cells were exposed to mild osmotic shock by addition of $20 \mathrm{ml}$ cold distilled water. After incubation with gentle shaking at $22^{\circ} \mathrm{C}$ for $2 \mathrm{~h}$, cell suspensions were centrifuged at $3500 \mathrm{~g}$ for $10 \mathrm{~min}$ at $4^{\circ} \mathrm{C}$. Filtersterilized supernatants were assayed for SOD, malate dehydrogenase $(\mathrm{MDH})$ and glutamine synthetase (GS) (see below).

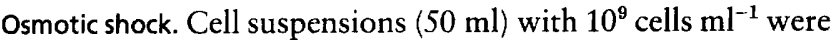
exposed to osmotic shock as previously described by Stabel $e t$ al. (1994). Cell suspensions were washed twice with an equal volume of cold $10 \mathrm{mM}$ Tris/ $\mathrm{HCl}, \mathrm{pH} 8,30 \mathrm{mM} \mathrm{NaCl}$. After centrifugation at $3500 \mathrm{~g}$ for $10 \mathrm{~min}$ at $4{ }^{\circ} \mathrm{C}$, washed cells were resuspended in $2.5 \mathrm{ml} 30 \mathrm{mM}$ Tris/ $\mathrm{HCl}, \mathrm{pH} 8,20 \%$ sucrose to which $10 \mathrm{ml} 250 \mathrm{mM}$ EDTA was added. The suspension was shaken at $22^{\circ} \mathrm{C}$ for $10 \mathrm{~min}$ and cells harvested by centrifugation at $3500 \mathrm{~g}$ for $10 \mathrm{~min}$ at $4^{\circ} \mathrm{C}$. Pelleted cells were resuspended in $2.5 \mathrm{ml}$ cold water, shaken for $10 \mathrm{~min}$ at $4{ }^{\circ} \mathrm{C}$ and centrifuged at $3500 \mathrm{~g}$ for $10 \mathrm{~min}$ at $4{ }^{\circ} \mathrm{C}$. Supernatants were filter-sterilized and assayed for $\mathrm{MDH}$ and GS. SOD activity was visualized on acrylamide gels.

Chloroform extraction. This was performed essentially according to Ames et al. (1984). Bacterial suspension $(50 \mathrm{ml})$ was centrifuged at $3500 \mathrm{~g}$ for $10 \mathrm{~min}$ at $4{ }^{\circ} \mathrm{C}$ and washed in saline solution $(0.145 \mathrm{M} \mathrm{NaCl})$. Supernatants were discarded, pellets resuspended in residual saline solution and chloroform $(100 \mu \mathrm{l})$ was added. After incubation at $22^{\circ} \mathrm{C}$ for $15 \mathrm{~min}, 0.5 \mathrm{ml}$ $10 \mathrm{mM}$ Tris $/ \mathrm{HCl}, \mathrm{pH} 8$, was added and whole cells were pelleted by centrifugation at $3500 \mathrm{~g}$ for $10 \mathrm{~min}$ at $4{ }^{\circ} \mathrm{C}$. The upper fraction of the supernatants was removed, filtersterilized and assayed for MDH and GS. SOD was visualized on acrylamide gels. A modification of the method described by Klotz \& Hutcheson (1992) was also employed. Bacterial suspensions were washed with $10 \mathrm{mM}$ Tris/ $\mathrm{HCl}, 30 \mathrm{mM}$

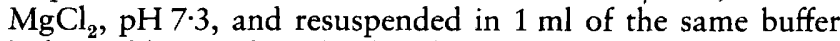
before addition of $15 \mu \mathrm{l}$ chloroform. After $15 \mathrm{~min}$ at $4{ }^{\circ} \mathrm{C}$, an additional volume of $1 \mathrm{ml}$ ice-cold buffer was added and the suspension was centrifuged at $3500 \mathrm{~g}$ for $10 \mathrm{~min}$ at $4^{\circ} \mathrm{C}$. Supernatants were carefully collected, filtered and assayed for SOD, MDH and GS.

Whole-cell extracts. Bacterial suspensions $(50 \mathrm{ml})$ were washed twice with $25 \mathrm{mM}$ sodium phosphate buffer containing $1 \mathrm{mM}$ disodium EDTA, pH 7.2, 0.5 mM PMSF and finally resuspended in $2 \mathrm{ml}$ buffer. Suspensions were sonicated on ice at $8 \mu \mathrm{m}$ for $90 \mathrm{~s}$ (six $15 \mathrm{~s}$ bursts with $15 \mathrm{~s}$ cooling periods) and then centrifuged at $16000 \mathrm{~g}$ for $45 \mathrm{~min}$ at $4{ }^{\circ} \mathrm{C}$. Supernatants were filtered and assayed for MDH, GS and SOD.

Enzyme assays. $\mathrm{MDH}$, a cytoplasmic marker enzyme (Smith \& Winkler, 1979), was assayed as described in Worthington Enzyme Manual (1993). Enzyme activity was calculated based on the decrease of $A_{340}$ at $25^{\circ} \mathrm{C}$ due to oxidation of NADH by the enzyme. Freshly prepared $6 \mathrm{mM}$ oxaloacetic acid $(0 \cdot 1 \mathrm{ml})$, $3.75 \mathrm{mM}$ NADH $(0.2 \mathrm{ml})$ (both prepared in $0.1 \mathrm{M}$ potassium phosphate buffer, $\mathrm{pH} \mathrm{7.4)}$ and $0.1 \mathrm{M}$ potassium phosphate buffer $\mathrm{pH} 7.4(2.6 \mathrm{ml})$ were placed in a $3 \mathrm{ml}$ cuvette, path length $1.0 \mathrm{~cm}$, at $25^{\circ} \mathrm{C}$. After incubating the cuvette in the spectrophotometer for 3-4 min to achieve temperature equilibration and establish blank rate, if any, $0.1 \mathrm{ml}$ of the sample was added to the cuvette and the decrease in $A_{340}$ was recorded for $10 \mathrm{~min}$. The rate of decrease in absorbance was calculated from the linear portion of the curve.

GS, also described as a cytoplasmic marker (Ames et al., 1984), was assayed according to Cánovas et al. (1991). GS activity was calculated based on the concentration of $\gamma$-glutamyl hydroxamate produced. The reaction was performed in vials containing $85 \mu \mathrm{l} 0.8 \mathrm{M}$ imidazole $/ \mathrm{HCl}, \mathrm{pH} 7,20 \mu \mathrm{l} 2.25 \mathrm{M}$ hydroxylamine, $20 \mu \mathrm{l} 0.75 \mathrm{M}$ sodium arsenate, $20 \mu \mathrm{l} 0 \cdot 11 \mathrm{M}$ manganese chloride, $20 \mu \mathrm{l} 15 \mathrm{mM} \mathrm{ADP}, 500 \mu \mathrm{l} 0 \cdot 18 \mathrm{M}$ glutamine, $65 \mu \mathrm{l}$ distilled water and $20 \mu \mathrm{l}$ of the sample. Blank tubes were prepared for each sample, replacing glutamine by an equal volume of distilled water. After incubation at $37^{\circ} \mathrm{C}$ for $15 \mathrm{~min}, 250 \mu \mathrm{l} \mathrm{GS}$ reagent $(10 \%$ ferric chloride in $0.2 \mathrm{M}$ $\mathrm{HCl}, 24 \% \mathrm{TCA}, 18 \cdot 5 \% \mathrm{HCl} ; 1: 1: 1)$ was added. Vial contents were shaken and placed in $1 \mathrm{ml}$ cuvettes with a $1.0 \mathrm{~cm}$ light path. $A_{540}$ was determined for each sample.

SOD was quantified using xanthine and xanthine oxidase as a source of superoxide and reduction of cytochrome $c$ as a detector of the presence of superoxide anions as described by McCord \& Fridovich (1969).

Enzyme stability. MDH, GS and SOD stability to the treatments used for spheroplasting was determined. Bacterial suspensions $(50 \mathrm{ml})$ with $10^{9}$ cells $\mathrm{ml}^{-1}$ were centrifuged and resuspended in $2 \mathrm{ml}$ of the solutions described for spheroplasting above and sonicated at $8 \mu \mathrm{m}$ for $90 \mathrm{~s}$ ( $\mathrm{six} 15 \mathrm{~s}$ bursts with $15 \mathrm{~s}$ cooling periods). After sonication, the spheroplast extraction protocols described above were applied to the crude extracts. $\mathrm{MDH}, \mathrm{GS}$ and SOD were quantified as described above. 
Localization of SOD with diazo-NDS. Diazo-NDS was prepared from 7-aminonaphthalene-1,3-disulphonic acid (Fluka) and sodium nitrite, as described by Pardee \& Watanabe (1968). Localization of SOD was determined as described by Britton \& Fridovich (1977). Briefly, a mid-exponential culture of $P$. damselae MT1415 (50 ml TSB-2) was washed in $50 \mathrm{mM}$ Tris/ $\mathrm{HCl}, 5 \mathrm{mM} \mathrm{MgCl}, \mathrm{pH} \mathrm{8.0,} \mathrm{and} \mathrm{resuspended} \mathrm{to} \mathrm{the}$ original density in the same buffer. The culture was split into two and one half was treated with the diazo-NDS compound (final concentration $5 \mathrm{mM}$ ), whilst the other was kept as control. The test and control were incubated at $25^{\circ} \mathrm{C}$ for $1 \mathrm{~h}$ and the reaction was quenched by addition of imidazole to $100 \mathrm{mM}$. Cells were washed extensively in $50 \mathrm{mM}$ Tris $/ \mathrm{HCl}$, $5 \mathrm{mM} \mathrm{MgCl}, \mathrm{pH} \mathrm{8.0,} \mathrm{and} \mathrm{resuspended} \mathrm{in} 5 \mathrm{ml}$ of the same solution. Cells were sonicated on ice as described above. Control sonicate was split into two; half was treated with $5 \mathrm{mM}$ diazo-NDS to determine the effect of the compound on SOD. Equal quantities of protein were analysed by native PAGE $(12 \%)$ and stained for SOD activity. Test, control and control lysates subsequently treated with diazo-NDS following lysis were assayed for GS as described above.

Determination of the type of SOD. The metal present in the active site of the SOD molecule was determined by using inhibition studies according to Dunlap \& Steinman (1986). Briefly, zones of activity attributable to $\mathrm{Cu} / \mathrm{ZnSODs}$ were identified by their elimination when $1.9 \mathrm{mM} \mathrm{KCN}$ was added to the staining mixture. Zones of FeSODs were identified by their resistance to cyanide and their elimination when $3.7 \mathrm{mM}$ $\mathrm{H}_{2} \mathrm{O}_{2}$ was present. Resistance to both cyanide and $\mathrm{H}_{2} \mathrm{O}_{2}$ is characteristic of MnSODs.

Estimation of native molecular mass. The native molecular mass of SOD from $P$. damselae strains was determined following the methodology described by Hedrick \& Smith (1968) based on the dependence of mobility of proteins on the acrylamide concentration. Cell extracts were electrophoresed on separate non-denaturing gels containing 8, 9,10,11, 12 and $13 \%$ acrylamide. The following proteins were used as molecular mass standards: $\alpha$-lactalbumin $(14200 \mathrm{Da})$, carbonic anhydrase (29000), chicken egg albumin (45000) and bovine serum albumin (monomer 66000; dimer 132000) (all from Sigma). SOD was visualized as described above and molecular mass markers were stained with Coomassie brilliant blue.

Effect of the presence of oxygen on SOD expression. Bacteria were cultured in aerobic and mild anaerobic conditions. For aerobic growth bacteria were cultured in $500 \mathrm{ml}$ flasks with a $5: 1$ ratio of flask volume to medium volume. Flasks were incubated at $22^{\circ} \mathrm{C}$ in a rotary shaker at 200 r.p.m. Anaerobic cultures were carried out in $100 \mathrm{ml}$ screw-capped Duran bottles filled to the top with medium and incubated at $22^{\circ} \mathrm{C}$ with very gentle agitation to avoid cell sedimentation. Samples were taken hourly from both cultures and $\mathrm{OD}_{540}$ was determined. The number of culturable cells was determined at different time intervals by viable cell counting on TSA-2.

Bacteria were cultured as described above under aerobic and mild anaerobic conditions until late exponential and stationary phase. Sonicates were prepared as described above and used to detect and quantify SOD as described above.

Effect of iron concentration on SOD production. Bacteria were cultured in TSB-2, TSB-2 containing $200 \mu \mathrm{M}$ ferric chloride $\left(\mathrm{FeCl}_{3}\right)$ or TSB-2 $+100 \mu \mathrm{M}$ dipyridyl (Sigma). Bacteria were twice passaged on the relevant medium prior to culture to deplete/augment iron stores. Cultures $(250 \mathrm{ml}$ broth in $500 \mathrm{ml}$ flasks) were incubated at $22^{\circ} \mathrm{C}$ at 150 r.p.m. for $48 \mathrm{~h}$ and used for preparation of sonicates. SOD quantity and type were determined under the various conditions.

Bacterial susceptibility to killing by cell-free-generated superoxide anion. Susceptibility of $P$. damselae to oxygen radical species was evaluated using a cell-free photochemical radical generating system described by Karczewski et al. (1991). Briefly, a $6.25 \mathrm{mM}$ methionine solution was prepared in PBS, $\mathrm{pH} 7 \cdot 2$, containing $4 \%$ glucose. Assay solutions containing $0 \cdot 2,0.1$ and $0.05 \mathrm{mM}$ riboflavin were prepared in the methionine solution. Bacterial suspensions $\left(10^{8}\right.$ c.f.u. $\left.\mathrm{ml}^{-1}\right)$ in PBS were diluted in the various riboflavin concentrations and applied to 96 -well microplates. $\mathrm{O}_{2}^{-}$was generated by photoreduction of riboflavin, methionine being used as hydrogen donor. Microplates were exposed to light from a light box for $10 \mathrm{~min}$ to initiate superoxide anion production and subsequently incubated in the dark for $5 \mathrm{~h}$ at $22^{\circ} \mathrm{C}$. After incubation, plates were centrifuged at $400 \mathrm{~g}$ for $10 \mathrm{~min}$ and the supernatants removed. TSB-2 was added to support bacterial growth and the plates were incubated at $22^{\circ} \mathrm{C}$ for $18 \mathrm{~h}$.

Bacterial viability was quantified by adding $10 \mu \mathrm{l} 3-$ (4,5-dimethylthiazol-2-yl)-2,5-diphenyltetrazolium bromide (MTT, $5 \mathrm{mg} \mathrm{ml}^{-1}$; Sigma) per well, according to Graham et al. (1988). After $15 \mathrm{~min}$ incubation at room temperature, the $\mathrm{OD}_{630}$ was determined using a microplate reader (System 7000 running Revelations Software, Dynatech). The suitability of the assay for determining viable numbers of $P$. damselae was verified prior to the experiment by correlating absorption of MTT at $630 \mathrm{~nm}$ with viable cell count determined on TSA-2. A linear range of cell numbers within which reduction of MTT accurately reflected viable counts was determined and the subsequent experiments were designed to fit within this range.

The effect of methionine or riboflavin separately on the viability of $P$. damselae was determined by performing the assay described in the presence of PBS, $4 \%$ glucose and $6.25 \mathrm{mM}$ methionine, or PBS, $4 \%$ glucose and $0.2,0.1$ or $0.05 \mathrm{mM}$ riboflavin, respectively.

The effect of the addition of catalase and SOD on the bactericidal activity of the radicals was determined by addition of catalase $\left(2400 \mathrm{U} \mathrm{ml}^{-1}\right)$, SOD $\left(1200 \mathrm{U} \mathrm{ml}^{-1}\right)$ or both to the wells. The effect of the addition of the inhibitor of SOD activity, sodium nitroprusside $(100 \mu \mathrm{M})$, on bacterial viability was also determined.

\section{RESULTS}

\section{Detection of SOD and catalase activity on acrylamide gels}

All strains included in this study showed a similar clear band of SOD activity on the gels (Fig. 1a). All bands migrated to the same point in $10 \%$ acrylamide gels, suggesting a similar enzyme was expressed by all strains. Identical protein concentrations were loaded for all the strains, thus the similar intensity of the SOD bands indicates that the $P$. damselae strains assayed contained similar levels of SOD activity.

The mobility of the bands of catalase activity in native gels was similar for all of the strains examined. Although this technique is not accurately quantitative, the differences in intensity of the bands suggests different levels of activity in the extracts of different strains (Fig. 1b). 
(a)

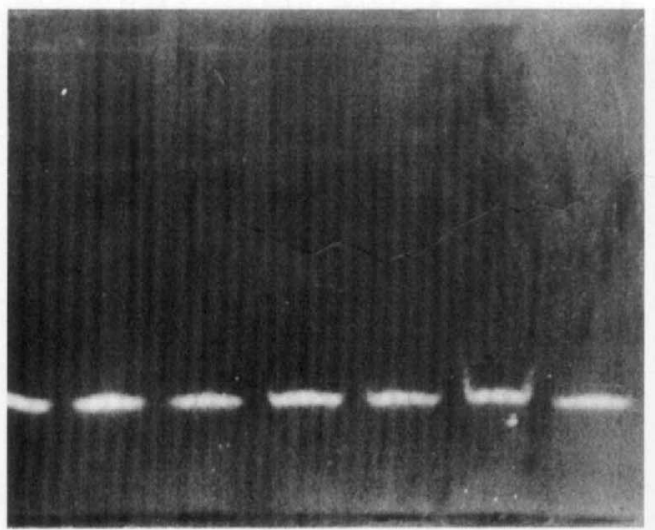

(b)

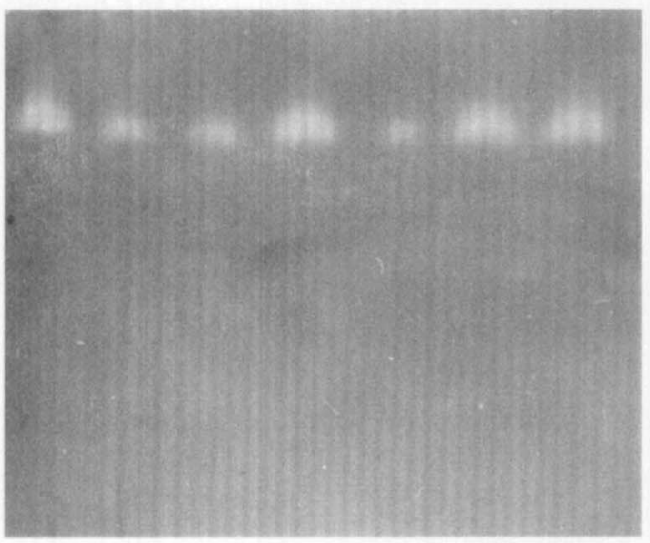

Fig. 1. $S O D$ and catalase activities detected in sonicated extracts of $P$. damselae subsp. piscicida. Gel stained for (a) SOD activity and (b) catalase activity.

Table 1. Stability of MDH, GS and SOD to the treatments used for spheroplasting

Values are relative to those obtained in sonicated samples.

\begin{tabular}{|lccc|}
\hline Treatment & MDH (\%) & GS (\%) & SOD (\%) \\
\hline CHAPS-lysozyme & $145 \cdot 0$ & $169 \cdot 0$ & $73 \cdot 4$ \\
Osmotic shock & $105 \cdot 0$ & $91 \cdot 0$ & $95 \cdot 8$ \\
Chloroform & $48 \cdot 2$ & $90 \cdot 2$ & 94.5 \\
\hline
\end{tabular}

\section{Intracellular location of SOD and catalase activities}

Assayed enzymes showed different degrees of stability to the treatments used for spheroplasting. When CHAPSlysozyme extraction or osmotic shock were applied to previously sonicated cells, higher levels of $\mathrm{MDH}$ activity were detected compared to sonicated extracts (Table 1). However, treatment with chloroform after sonication significantly inhibited $\mathrm{MDH}$ activity. Indeed, only $48 \cdot 2 \%$ of the initial activity could be detected (Table 1 ). In contrast, GS was not significantly affected by any of the spheroplasting protocols. Thus, this enzyme was
Table 2. Protein, GS and SOD content of periplasmic extracts prepared by different methods

Values are relative to those obtained in sonicated samples.

\begin{tabular}{|lcrc|}
\hline Treatment & Protein (\%) & GS (\%) & SOD (\%) \\
\hline CHAPS-lysozyme & $98 \cdot 0$ & 56.8 & $81 \cdot 0$ \\
Osmotic shock & 28.5 & $9 \cdot 7$ & 24.2 \\
Chloroform $\left(22^{\circ} \mathrm{C}\right)$ & 20.0 & $<1 \cdot 0$ & 62.6 \\
Chloroform $\left(4^{\circ} \mathrm{C}\right)$ & $2 \cdot 6$ & $<1 \cdot 0$ & $1 \cdot 7$ \\
\hline
\end{tabular}

selected in favour of MDH as a cytoplasmic marker in this study.

SOD showed stability to the treatments used for osmotic shock and chloroform extractions. However, the use of the detergent CHAPS with lysozyme resulted in the loss of more than $25 \%$ activity.

Four methods to selectively release periplasmic contents of $P$. damselae cells without cytoplasmic contamination were compared. Screening of periplasmic extracts for GS activity recorded the highest levels of the enzyme in sonicated fractions. The lowest activity was detected in chloroform-treated samples, representing less than $1 \%$ of the total GS observed in sonicated extracts (Table 2). Due to the low level of cytoplasmic contamination, chloroform was considered the most suitable extraction protocol for release of periplasmic proteins.

Different levels of SOD activity from the different methods were observed on polyacrylamide gels, the maximum activity corresponding to sonicated samples. Bands corresponding to SOD activity were less intense in samples from CHAPS-lysozyme, osmotic shock and chloroform extraction at $4^{\circ} \mathrm{C}$ than in periplasmic fractions obtained by extraction with chloroform at $22^{\circ} \mathrm{C}$. The different methods used in this study resulted in variable volumes of periplasmic extracts. Thus although some treatments like CHAPS-lysozyme released a high percentage of the protein content of the cells (Table 2), the high level of dilution of the samples required by the protocol did not make it possible to obtain extracts with high protein concentrations. When extracts from sonicated and chloroform-treated samples containing equal amounts of protein were loaded on the gels, a more intense band of SOD activity was found in chloroform extracts than in sonicated samples, showing that SOD represents a higher proportion of the total protein content in periplasmic extracts obtained with chloroform than in sonicated samples. In sonicated samples, both periplasmic and cytoplasmic proteins were released during the treatment.

Quantification of SOD activity obtained in periplasmic extracts and sonicated cells showed that CHAPSlysozyme extraction released the highest percentage of activity. However, the high level of cytoplasmic contamination shown by GS contents indicates that this method cannot conclusively locate SOD activity in the periplasmic space. In contrast, the high percentage of 
(a)

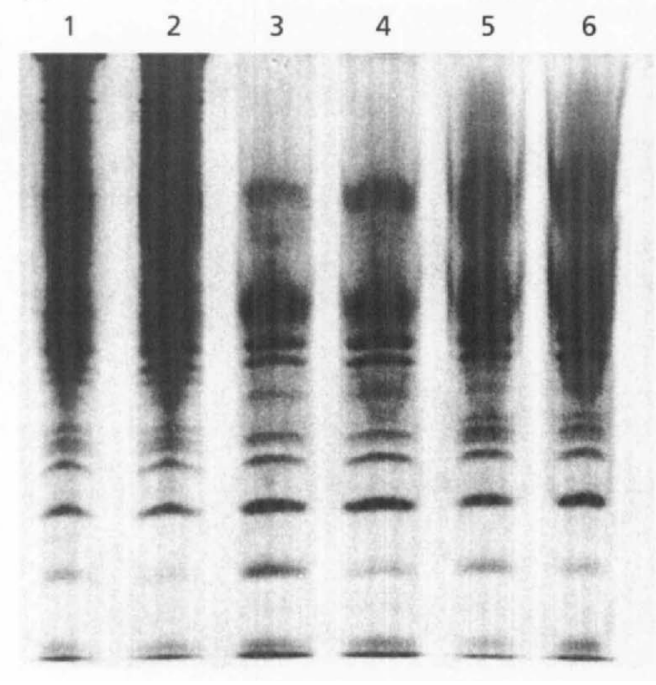

(b)

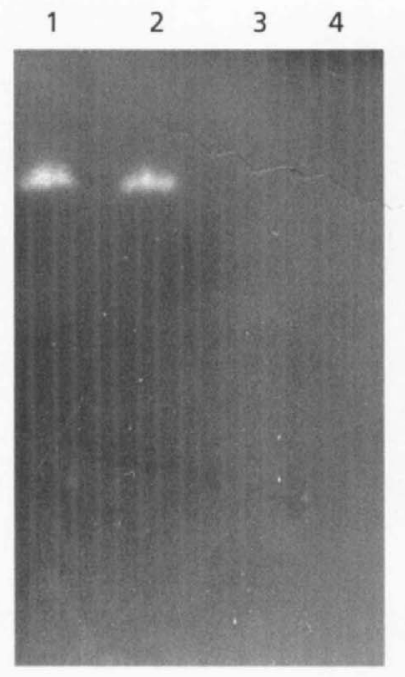

Fig. 2. Protein and catalase activity in sonicated and periplasmic fractions of $P$. damselae subsp. piscicida MT1415. (a) Gel stained with Coomassie brilliant blue. Lanes: 1,2 , sonicates; 3,4 , osmotic shock extract; 5 , 6, chloroform extraction according to Ames et al. (1984). (b) Gel stained for catalase activity. Lanes: 1, 2, sonicates; 3, osmotic shock; 4, chloroform extraction according to Ames et al. (1984).
SOD activity coupled with very low cytoplasmic contamination indicates that chloroform extraction at $22^{\circ} \mathrm{C}$ is the most appropriate method for isolating SOD from the periplasmic space in $P$. damselae. The periplasmic location of SOD was confirmed using diazo-NDS. This reagent does not penetrate the cytoplasmic membrane, but can easily enter the periplasmic space where it may inactivate certain enzyme activities by coupling with histidine and tyrosine residues (Pardee \& Watanabe, 1968). It has previously been used to disprove the proposed periplasmic location of FeSOD in Escherichia coli (Britton \& Fridovich, 1977). In this study, diazoNDS was shown to inactivate SOD and GS in sonicates of $P$. damselae but, in contrast to the observations made in E. coli (Britton \& Fridovich, 1977), it inhibited SOD activity when whole cells were treated with the compound, suggesting periplasmic location of the enzyme. GS, a cytoplasmic enzyme, was not inhibited when whole cells were treated with diazo-NDS, confirming that the compound was unable to permeate the cytoplasmic membrane.

Chloroform extraction according to Ames et al. (1984) was selected to determine the intracellular location of catalase in P. damselae cells. Treatment of sonicated extracts with chloroform following the protocol described for spheroplasting did not result in different intensity bands of catalase activity in acrylamide gels, indicating that catalase is stable to this process. No catalase activity was observed when periplasmic extracts were applied to the gels, thus indicating that catalase is not located in the periplasmic space of $P$. damselae (Fig. 2).

\section{Determination of type and approximate native molecular mass of SOD}

In all cases, clear bands corresponding to SOD activity persisted after the addition of $1.9 \mathrm{mM} \mathrm{KCN}$ in the staining mixture (Fig. 3). However, this activity was sensitive to $\mathrm{H}_{2} \mathrm{O}_{2}$, indicating that the SOD present in these strains is probably a ferric enzyme. The native molecular mass of SOD from $P$. damselae was estimated to be $39 \cdot 8 \mathrm{kDa}$.

\section{Purification and amino-terminal sequencing of SOD}

SOD was purified from sonicates by a combination of gel filtration and anion exchange chromatography. Purified SOD had a specific activity of approximately $1000 \mathrm{U}$ (mg protein $)^{-1}$. Partially purified SOD, following Superose 6 and the first passage on a Mono-Q column, resulted in a specific activity of $910 \mathrm{U}$ (mg protein $)^{-1}$, suggesting $>90 \%$ purity was achieved after these two steps. SDS-PAGE of purified SOD in reducing sample buffer, followed by Western blotting and staining with Aurodye, resulted in a single band with an approximate molecular mass of $25 \mathrm{kDa}$ (Fig. 4). Amino-terminal sequencing of the first 20 residues, coupled with a database search using ow (on the Leeds University database browser) revealed that SOD from $P$. damselae showed a high degree of sequence homology to other bacterial FeSODs (Table 3).

\section{Effect of the presence of oxygen on SOD expression}

$P$. damselae strains grew at different rates when cultured under aerobic or mild anaerobic conditions. Fig. 5 shows that cells cultured in highly aerated flasks reached stationary phase after $38 \mathrm{~h}$, whilst cells grown under mild anaerobic conditions experienced a shorter exponential phase reaching stationary phase after $20 \mathrm{~h}$ with a lower OD.

Extracts from cells grown under aerobic conditions contained higher specific SOD activity $[28.8 \pm 0.5 \mathrm{U}(\mathrm{mg}$ protein $)^{-1}$ compared to those from low oxygen cultures $\left.[8.1 \pm 0.8 \mathrm{U} \text { (mg protein })^{-1}\right]$ when assayed in late exponential phase. Inhibitory studies with $\mathrm{KCN}$ and $\mathrm{H}_{2} \mathrm{O}_{2}$ showed that $P$. damselae cells grown to exponential or 
(a)

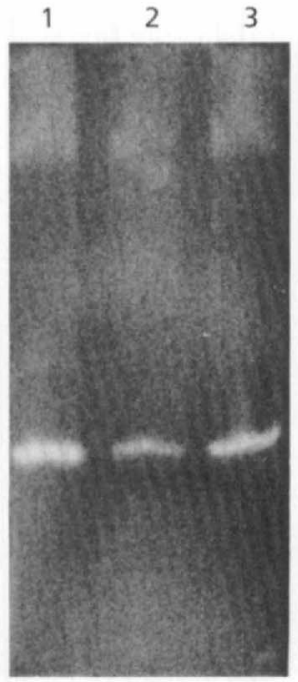

(c)

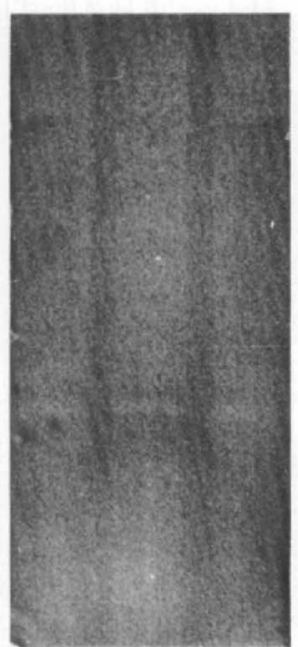

(b)

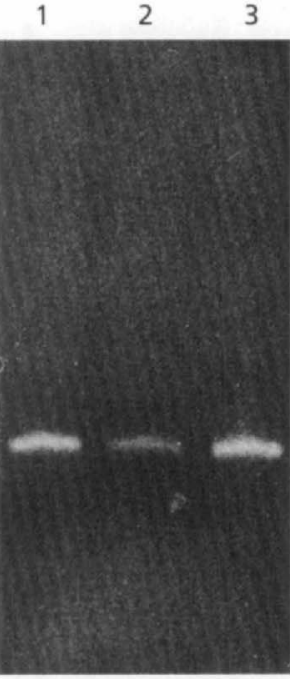

(d)

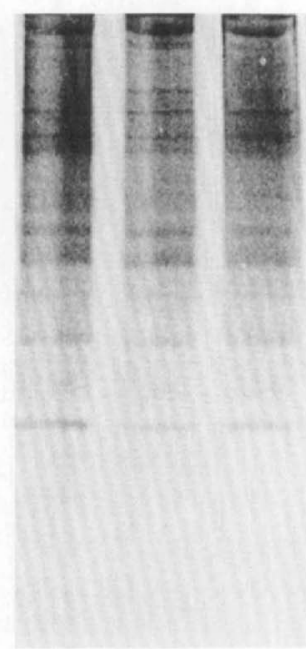

Fig. 3. Inhibitory effect of $\mathrm{KCN}$ and $\mathrm{H}_{2} \mathrm{O}_{2}$ on SOD activity from cells grown under differing iron concentrations. Gel stained (a) for catalase with no inhibitor, (b) for SOD in the presence of $1.9 \mathrm{mM} \mathrm{KCN},(c)$ for SOD in the presence of $3.7 \mathrm{mM} \mathrm{H}_{2} \mathrm{O}_{2}$ and (d) with Coomassie brilliant blue. Lanes: 1, sonicate from bacteria cultured in TSB-2; 2 , sonicate from bacteria cultured in TSB-2 with $100 \mu \mathrm{M}$ dipyridyl; 3, sonicate from bacteria cultured in TSB-2 with $200 \mu \mathrm{M} \mathrm{FeCl}_{3}$.

stationary phase produce FeSOD under both aerobic and mild anaerobic conditions.

\section{Effect of iron concentration on SOD production}

Growth under normal, iron-supplemented and irondepleted conditions did not result in a different SOD activity band on acrylamide gels. In all cases it was possible to observe a similar band on the gels that was inhibited by $\mathrm{H}_{2} \mathrm{O}_{2}$ but was resistant to $\mathrm{KCN}$. However, specific SOD activity was affected by iron-depleted conditions. Cells grown in the presence of $100 \mu \mathrm{M}$

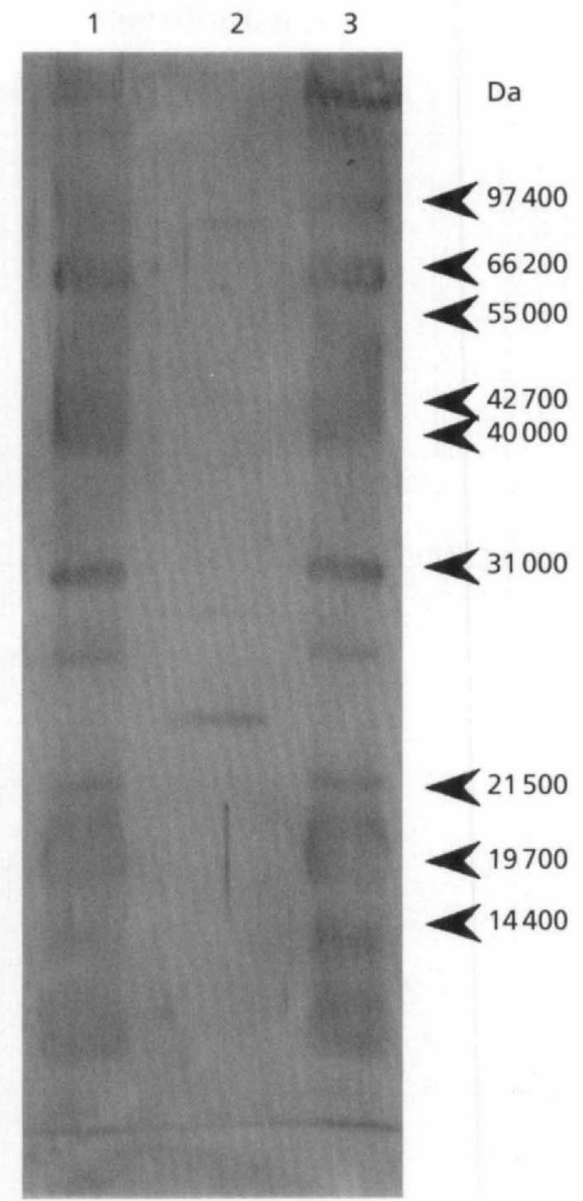

Fig. 4. SDS-PAGE of purified SOD, blotted onto immobilon $P$ and stained with Aurodye. Lanes: 1, 3, Promega mid-range markers (phosphorylase B, $97400 \mathrm{Da}$; bovine serum albumin, 66200; glutamate dehydrogenase, 55000; ovalbumin, 42700; aldolase, 40000; carbonic anhydrase, 31000 ; soybean trypsin inhibitor doublet 21500/19700; lysozyme, 14400); 2, purified SOD.

dipyridyl contained only $7 \cdot 1 \%$ SOD activity $[1 \cdot 6 \pm 0 \cdot 2 \mathrm{U}$ (mg protein $)^{-1}$ ] detected in cells grown in normal TSB$\left.2[22 \cdot 0 \pm 0.2 \mathrm{U} \text { (mg protein })^{-1}\right]$ or iron-supplemented TSB-2 [22.5 $\left.\pm 0.4 \mathrm{U}(\mathrm{mg} \text { protein })^{-1}\right]$.

\section{Bacterial susceptibility to killing by superoxide anion}

Susceptibility to oxygen radical species generated in vitro was determined for two strains selected according to their virulence: MT1415 from sea bream affected with pasteurellosis and ATCC 29690, a strain avirulent for sea bream (Magariños et al., 1992). Superoxide anions were generated photochemically from a range of concentrations of riboflavin, with methionine as electron donor.

Both strains showed high susceptibility to the radicals generated in this cell-free system and no differences were observed between the strains. Thus the decrease in cell viability in terms of $\mathrm{OD}_{630}$ due to reduction of MTT has 
Table 3. Amino-terminal amino acid sequence of $P$. damselae and closely related bacterial SODs

Sequences for bacteria other than P. damselae obtained from ow . Underlined residues differ from the P. damselae sequence.

\begin{tabular}{|c|c|c|c|c|c|c|c|c|c|c|c|c|c|c|c|c|c|c|c|c|c|}
\hline Species & SOD type & 1 & & & & 5 & & & & & 10 & & & & & 15 & & & & & 20 \\
\hline Photobacterium damselae & $\mathrm{Fe}$ & ala & phe & glu & leu & pro & ala & leu & pro & tyr & ala & lys & asp & ala & leu & glu & pro & his & ile & ser & ala \\
\hline Pseudomonas aeruginosa & $\mathrm{Fe}$ & ala & phe & glu & leu & pro & pro & leu & pro & tyr & glu & lys & asn & ala & leu & glu & pro & his & ile & ser & ala \\
\hline Escherichia coli & $\mathrm{Fe}$ & $\underline{\text { ser }}$ & phe & glu & leu & pro & ala & leu & pro & tyr & ala & lys & asp & ala & leu & ala & pro & his & ile & ser & ala \\
\hline Salmonella typhimurium & $\mathrm{Fe}$ & $\overline{\text { ser }}$ & phe & glu & leu & pro & ala & leu & pro & tyr & ala & lys & asp & ala & leu & ala & pro & his & ile & ser & ala \\
\hline Pseudomonas putida & $\mathrm{Fe}$ & $\overline{\text { ala }}$ & phe & glu & leu & pro & pro & leu & pro & tyr & ala & $\underline{\text { his }}$ & asp & ala & leu & $\operatorname{gln}$ & pro & his & ile & ser & ala \\
\hline Photobacterium leiognathi & $\mathrm{Fe}$ & ala & phe & glu & leu & pro & ala & leu & pro & phe & ala & met & asn & ala & leu & glu & pro & his & ile & ser & $\mathrm{gln}$ \\
\hline Escherichia coli & $\mathrm{Mn}$ & ser & tyr & thr & leu & pro & ser & leu & pro & tyr & ala & $\underline{\text { tyr }}$ & asp & ala & leu & glu & pro & his & phe & asp & lys \\
\hline Bovine erythrocyte & $\mathrm{Cu} / \mathrm{Zn}$ & $\overline{\text { ala }}$ & thr & $\overline{\text { yss }}$ & ala & val & cys & yal & leu & lys & gly & $\overline{\text { asp }}$ & gly & pro & val & $\operatorname{gln}$ & gly & thr & ile & $\underline{\text { his }}$ & phe \\
\hline
\end{tabular}

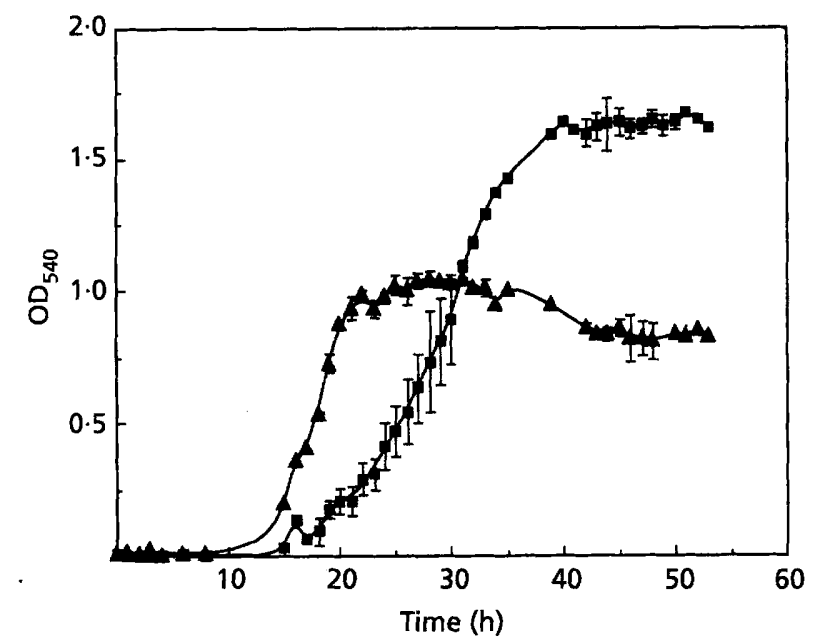

Fig. 5. Growth curves for $P$. damselae subsp. piscicida MT1415 cultured under aerobic ( $\mathbf{D})$ and mildly anaerobic (A) conditions.

been shown only for one strain (Fig. 6). This killing was not reduced by addition of SOD to the system, suggesting the involvement of killing mechanisms other than $\mathrm{O}_{2}^{-}$. However, addition of catalase or both SOD and catalase to the medium greatly reduced bacterial killing. Addition of $100 \mu \mathrm{M}$ sodium nitroprusside, a SOD inhibitor, did not make any difference to bacterial killing compared to controls (data not shown).

It was observed that increasing concentrations of riboflavin overcame the protective effect of catalase, and SOD and catalase. This inactivation was not due to toxicity of riboflavin or methionine, since cell viability in the presence of each of these compounds separately was not affected. Some inactivation was detected even with the lowest riboflavin concentration used in the presence of the enzymes. These results show the high susceptibility of $P$. damselae to the oxygen radical species, or metabolites thereof, generated in this system.

\section{DISCUSSION}

SODs, which catalyse the dismutation of $\mathrm{O}_{2}{ }^{-}$, may be the first line of defence against oxygen toxicity. We have found that all the strains of $P$. damselae included in this study contain SOD activity. A single band of SOD activity was observed on acrylamide gels, indicating the presence of one type of SOD with an estimated native molecular mass of $39.8 \mathrm{kDa}$. Inhibitory studies with $\mathrm{KCN}$ and $\mathrm{H}_{2} \mathrm{O}_{2}$ indicated this SOD is a ferric enzyme. Amino-terminal sequencing corroborated this finding, with $P$. damselae SOD having $>90 \%$ homology with numerous other bacterial FeSODs. Purification followed by SDS-PAGE of the purified enzyme revealed a single band with a molecular mass of approximately $25 \mathrm{kDa}$ after Coomassie staining. Most bacterial SODs comprise two subunits of equal size, with the metal cofactor at the active site (Yost \& Fridovich, 1973; Keele et al., 1970). The molecular mass determined under reducing conditions suggests two subunits of $25 \mathrm{kDa}$ each, giving a total native molecular mass of $50 \mathrm{kDa}$.

Several types of SOD have been found in different bacterial species such as E. coli (Gregory et al., 1973), Legionella pneumophila (St John \& Steinman, 1996) and Aeromonas salmonicida (Barnes et al., 1996). In many cases, one type of SOD is located in the periplasmic space of the cell, possibly contributing to the elimination of $\mathrm{O}_{2}^{-}$generated extracellularly or at the membrane, while the other types may be found in the cytoplasm. In this study, only one SOD enzyme, the FeSOD located in the periplasm, was identified in P. damselae.

Pathogens must compete with the host for iron and the ability of pathogenic bacteria to acquire iron is essential for their growth in vivo. Magariños et al. (1994) observed that iron overload had an enhancing effect on the virulence of $P$. damselae for fish. When fish were treated with ferric ammonium citrate, haemin or haemoglobin, prior to bacterial inoculation, $\mathrm{LD}_{50}$ values were reduced by as much as $4 \log$ units. Results obtained by these authors showed that $P$. damselae has the ability to obtain iron from transferrin and haem compounds. In this study, a retardation in the growth of $P$. damselae was observed when cultured under iron-restricted conditions. Assuming that SOD contributes to the pathogenicity of $P$. damselae, the reliance on an ironcontaining SOD could partially explain the enhancing effect of iron on the virulence of this pathogen and the reduced growth rate when iron is limiting. Furthermore, free iron contributes to oxidative stress in bacteria through its involvement in Fenton reactions, catalysing 

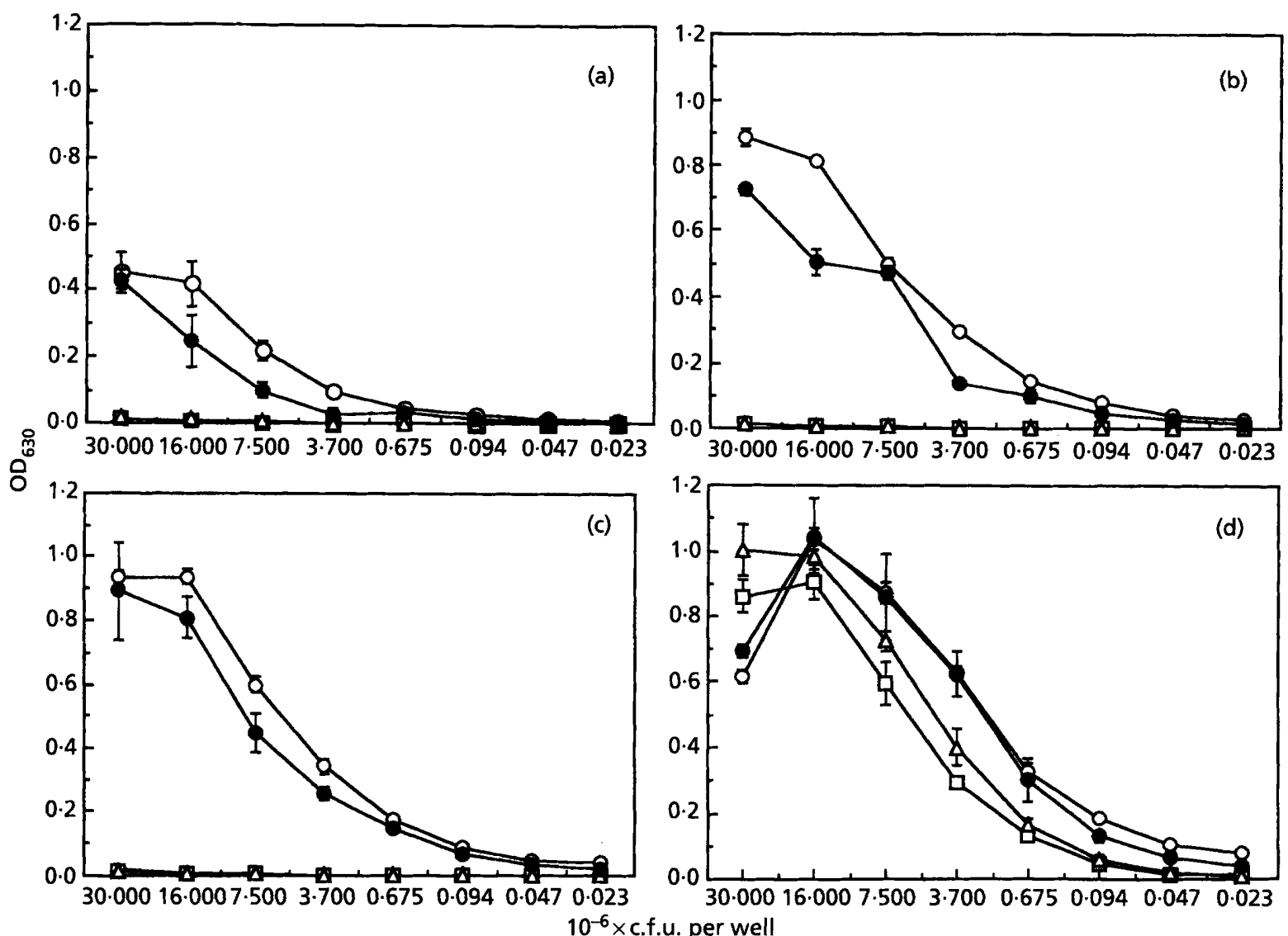

Fig. 6. Effect of $5 \mathrm{~h}$ exposure to photochemically generated oxygen radicals on viability of $P$. damselae subsp. piscicida MT1415. Assays contained (a) 0.2, (b) 0.1 and (c) $0.05 \mathrm{mM}$ riboflavin; controls (d) were performed in the absence of riboflavin. Enzymes added: none $(\square)$; $\operatorname{SOD}\left(\triangle, 1200 \mathrm{U} \mathrm{ml}^{-1}\right)$; catalase $\left(O, 2400 \mathrm{U} \mathrm{ml}^{-1}\right)$; both SOD and catalase $(O)$. Viability was determined by measurement of MTT reduction at $630 \mathrm{~nm}$. Data are means $\pm S D$ of triplicate values.

the formation of hydroxyl radicals from peroxide (Halliwell \& Gutteridge, 1984). This reduction in overall iron load may result in a reduced requirement for SOD as the potential for oxidative damage is reduced.

SODs have been reported to be regulated by oxygensensitive systems in several organisms (Tardat \& Touati, 1991; Fridovich, 1995). In P. damselae, SOD levels detected in cells grown under highly aerated and nonaerated conditions suggest that SOD may be repressed under low aeration. A significant increase in specific SOD activity per cell was observed in cells grown in aerated conditions for $30 \mathrm{~h}$. This activity decreased when cells were old and the culture was in stationary phase (48 h incubation), possibly due to bacterial death. Lower levels of SOD present in cells cultured under mild anaerobic conditions could be sufficient to cope with $\mathrm{O}_{2}{ }^{-}$generated from the lower levels of oxygen present in the medium. Moreover, as Fridovich (1995) reported, the presence of a certain minimal level of SOD helps the cell to survive if it is suddenly exposed to an aerobic environment. Interestingly, cells cultured under anaerobic conditions grew more quickly and reached stationary phase earlier than those grown under aerobic conditions, albeit with a lower final OD. This may result from the low amount/absence of SOD in the cytoplasm, making aerobic growth stressful on the bacterium.

While some species such as Enterococcus faecalis lack catalase activity, different isozymes have been identified in other species such as Pseudomonas syringae (Klotz \& Hutcheson, 1992). In this study only one type of catalase was detected in all the strains of $P$. damselae analysed, according to migration in acrylamide gels. However, the intensity of the bands differed among the strains.

Cell fractionation was used to determine the intracellular location of SOD and catalase. Attempts to form spheroplasts by different methods yielded different results. Production of spheroplasts by chloroform at $22{ }^{\circ} \mathrm{C}$ confirmed the presence of periplasmic SOD in $P$. damselae. The low levels of GS activity in the extracts obtained by treatment with chloroform, both at $22{ }^{\circ} \mathrm{C}$ and $4{ }^{\circ} \mathrm{C}$, indicate that both methods successfully prevent cytoplasmic contamination during spheroplasting. However, the incubation at $4{ }^{\circ} \mathrm{C}$ in the presence of $10 \mathrm{mM}$ Tris $/ \mathrm{HCl}, 30 \mathrm{mM} \mathrm{MgCl}{ }_{2}$ and $150 \mu$ chloroform did not allow the visualization of SOD activity on 
polyacrylamide gels and low SOD activity was detected in the extracts. This method probably resulted in a much lower degree of spheroplasting as the low total protein content of the extracts confirmed.

Some proteins are inactivated by exposure to chloroform (Ames et al., 1984). This was the case for $\mathrm{MDH}$, commonly used as a cytoplasmic marker. Although this enzyme does not seem to be inactivated after osmotic shock, a different cytoplasmic marker had to be selected when chloroform was used for preparation of spheroplasts. GS was not significantly inactivated by any of the methods used in this study and thus was selected as the enzyme of choice for detecting cytoplasmic contamination. In this study, the use of chloroform to obtain spheroplasts, coupled with assay of GS to estimate cytoplasmic contamination, was found most appropriate in establishing the periplasmic location of SOD and the absence of catalase in this region in P. damselae.

The location of FeSOD in the periplasm is unusual, with the early reports of periplasmic FeSOD in E. coli (Gregory et al., 1973) having been subsequently disproven (Britton \& Fridovich, 1977). The only precedent for periplasmic FeSOD is that of Aquaspirillum magnetotacticum which possesses FeSOD and MnSOD, both of which are located periplasmically (Short \& Blakemore, 1989). However, the identity of the SOD in this study was supported both by inhibitor studies and by aminoterminal sequencing. The evidence locating the enzyme in the periplasm is also compelling, with the absence of GS and catalase activity in periplasmic extracts confirming the suitability of the extraction procedure. Further corroboration is presented by inactivation of SOD in whole cells after treatment with diazo-NDS, the same technique used to disprove the periplasmic location of E. coli FeSOD (Britton \& Fridovich, 1977). Any explanation for the opposing locations of SOD and catalase in $P$. damselae would be complex as a result of the numerous theories relating to the mechanisms of oxygen radical toxicity presented in the literature. In aqueous environments the reactivity and oxidizing capacity of $\mathrm{O}_{2}{ }^{-}$are very low (Halliwell \& Gutteridge, 1984). However, in non-polar environments $\mathrm{O}_{2}{ }^{-}$is a powerful proton acceptor, nucleophile and reducing agent (Frimer, 1982; Halliwell \& Gutteridge, 1984). Biological membranes, including the bacterial cell envelope and outer membrane, are known to be hydrophobic and $\mathrm{O}_{2}^{-}$produced in this environment could be extremely damaging, destroying phospholipids. Halliwell (1981) reported that much of the $\mathrm{O}_{2}^{-}$formed within cells is generated by membrane-bound systems. Furthermore, oxygen is more soluble in non-polar solvents than in aqueous solutions. One may speculate, therefore, that $P$. damselae has greater need of a superoxide detoxifying enzyme at the membrane where the radical can inflict the greatest damage.

However, using this model, the question of protection against oxidative DNA damage in the cytoplasm remains unanswered. Halliwell \& Gutteridge (1984) proposed a model for $\mathrm{O}_{2}^{-}$-mediated generation of hydroxyl radicals based on a Haber-Weiss-type Fenton reaction in which $\mathrm{O}_{2}^{-}$reduces iron salts to produce $\mathrm{Fe}$ (II). Oxidation of $\mathrm{Fe}$ (II) to $\mathrm{Fe}$ (III) by simultaneous reduction of peroxide then generates the hydroxyl radical. This model suggests a role for superoxide of merely transferring electrons to free iron. However, biological reductants such as thiols and NADH are far more abundant in the cell (Imlay \& Fridovich 1991) and are equally capable of performing this task (Winterbourn, 1979; Imlay \& Linn, 1988). Thus Keyer et al. (1995) presented data consistent with oxidative excision of iron by $\mathrm{O}_{2}^{-}$from $[4 \mathrm{Fe}-4 \mathrm{~S}]$ clusters in dehydratases, increasing the pool of free iron for catalysis of oxidative DNA damage. The means by which $P$. damselae counters this form of oxidative damage cannot be answered conclusively from data presented in this paper. Certainly, cytoplasmic catalase is important in protection against such damage by removing cytoplasmic $\mathrm{H}_{2} \mathrm{O}_{2}$, the precursor of hydroxyl radicals. However, as no accurate quantification was made of the percentage, if any, of SOD present in the cytoplasm, it is not possible to comment on the fate of any free $\mathrm{O}_{2}{ }^{-}$generated in the cytoplasm. Current models for protein secretion do not preclude the FeSOD from being predominant in the periplasm with small quantities remaining in the cytoplasm (Randall \& Hardy, 1989). Following transient interaction with the leader peptide, protein folding is modulated such that interaction with export apparatus is kinetically favoured over folding to produce the mature protein. As a result, the bulk of leader-associated proteins are exported, but this does not rule out a small proportion folding into an active export-incompetent state within the matrix (Randall \& Hardy, 1989)

The present results demonstrate that $P$. damselae is susceptible to reactive oxygen species. Exposure of bacteria to photoreduced riboflavin in the presence of methionine resulted in a significant reduction in bacterial survival compared to the controls. The bactericidal effect was abolished by addition of catalase, but not exogenous SOD to the medium. The periplasmic location of SOD suggests that $P$. damselae cells should be able to protect against exogenous superoxide anions and this may, in fact, be the case. However, in the strains examined, catalase was absent from the periplasm. In addition, there is no induction of catalase in response to sublethal concentrations of peroxide (unpublished data). This suggests that the weak link in the oxidative defence strategies of $P$. damselae lies in dealing with $\mathrm{H}_{2} \mathrm{O}_{2}$ generated by SOD in the periplasm. The protection afforded by addition of catalase to the killing assays corroborates this hypothesis. Furthermore, the addition of both SOD and catalase simultaneously to the bactericidal assays did not make a significant difference to protection against $\mathrm{O}_{2}{ }^{-}$compared with the addition of catalase alone. This suggests that $P$. damselae contains sufficient SOD activity to disproportionate exogenous $\mathrm{O}_{2}^{-}$but that the susceptibility to killing results from accumulation of $\mathrm{H}_{2} \mathrm{O}_{2}$. Although all the strains assayed here produced a catalase, the level of activity detected in gels appeared to vary between strains. It would be of 
interest to know if strains producing higher levels of catalase are more resistant to killing by reactive oxygen species.

Several authors have postulated that $P$. damselae can survive within fish macrophages: histopathological studies carried out by Kubota et al. (1970) and Nelson et al. (1981) showed the presence of yellowtail macrophages with engulfed intact bacteria. Noya et al. (1995b) also reported the existence of unaffected $P$. damselae cells within macrophages of gilthead sea bream weighing $0.5 \mathrm{~g}$. However, the same authors indicated that macrophages from larger sea bream $(20-30 \mathrm{~g})$ killed the pathogen. Furthermore, Skarmeta et al. (1995) reported that macrophages from sea bass and sea bream killed the bacterium in vitro and observed that superoxide anions generated in vitro are implicated in the killing process of P. damselae.

The present data indicate that $P$. damselae is ill-equipped to protect itself from the bactericidal products of phagocyte respiratory burst and hence corroborate the findings of Skarmeta et al. (1995). Future work may be fruitfully directed towards studies of how the bacterium might avoid phagocytosis to survive in the host. Some recent work is of interest in this context; virulent strains of $P$. damselae possess a polysaccharide capsule which confers resistance to normal serum killing (Magariños et al., 1996). Also, while non-capsulated strains are opsonized by normal serum, capsulated strains are not (Arijo et al., 1998). Thus the presence of a capsule may reduce the opportunities of fish macrophages to phagocytose the bacterium in vivo. Furthermore, $P$. damselae is highly invasive in fish epithelial tissue culture cell lines with evidence of actin polymerization and cell to cell migration (Magariños et al., 1996). Unpublished observations in our laboratory have confirmed these results in EM studies and the ability of $P$. damselae to reside within EPC and Sea Bass Larval cell lines has been observed. Thus, $P$. damselae, while lacking defences against the bactericidal activities of macrophages, may avoid phagocytosis by growing in non-phagocytic host cells and producing an anti-opsonizing capsule when in the extracellular milieu. One may speculate that the increased growth rate observed during anaerobic culture reflects a preference for survival in non-phagocytic host cells, where oxygen will be in short supply.

\section{ACKNOWLEDGEMENTS}

M. C. Balebona was supported by a grant from the European Commission (FAIR GT95 2642). A. C. Barnes is an employee of Aqua Health Europe Ltd. We are grateful to Dr Brian Dunbar of the Protein Facility, Department of Molecular and Cell Biology, University of Aberdeen for sequencing SOD and for his helpful advice. Finally, we are grateful to the referees for their helpful comments and guidance.

\section{REFERENCES}

Ames, G. F.-L., Prody, C. \& Kustu, S. (1984). Simple, rapid and quantitative release of periplasmic proteins by chloroform. $J$ Bacteriol 160, 1181-1183.
Arijo, S., Borrego, J. J., Zorrilla, I., Balebona, M. C. \& Moriñigo, M. A. (1998). Role of the capsule of Photobacterium damselae subsp. piscicida in protection against phagocytosis and killing by sea bream (Sparus aurata L.) macrophages. Fish Shellfish Immunol 8, 63-72.

Balebona, M. C., Moriñigo, M. A., Sedano, S., MartínezManzanares, E., Vidaurreta, A., Borrego, J. J. \& Toranzo, A. E. (1992). Isolation of Pasteurella piscicida from sea bass in southwestern Spain. Bull Eur Assn Fish Patbol 12, 1-3.

Bandín, I., Ellis, A. E., Barja, J. L. \& Secombes, C. J. (1993). Interaction between rainbow trout macrophages and Renibacterium salmoninarum in vitro. Fish Shellfish Immunol 3, 25-33.

Barnes, A. C., Horne, M. T. \& Ellis, A. E. (1996). Effect of iron on expression of superoxide dismutase by Aeromonas salmonicida and associated resistance to superoxide anion. FEMS Microbiol Lett 142, 19-26.

Beaman, L. \& Beaman, B. L. (1984). The role of oxygen and its derivatives in microbial pathogenesis. Annu Rev Microbiol 38, $27-48$.

Beauchamp, C. \& Fridovich, I. (1971). Superoxide dismutase: improved assays and an assay applicable to acrylamide gels. Anal Biochem 44, 276-287.

Britton, L. \& Fridovich, I. (1977). Intracellular localization of the superoxide dismutases of Escherichia coli: a re-evaluation. $J$ Bacteriol 131, 815-820.

Cánovas, F. M., Cantón, F. R., Gallardo, F., García-Gutiérrez, A. \& de Vicente, A. (1991). Accumulation of glutamine synthetase during early development of maritime pine (Pinus pinaster) seedlings. Planta $185,372-378$.

Dunlap, P. V. \& Steinman, H. M. (1986). Strain variation in bacteriocuprein superoxide dismutase from symbiotic Photobacterium leiognathi. J Bacteriol 165, 393-398.

Franzon, V. L., Arondel, I. \& Sansonetti, P. I. (1990). Contribution of superoxide dismutase and catalase activities to Shigella flexneri pathogenesis. Infect Immun 58, 529-535.

Fridovich, I. (1995). Superoxide radical and superoxide dismutases. Annu Rev Toxicol 64, 97-112.

Frimer, A. A. (1982). Organic chemistry of superoxide anion radical. In Superoxide Dismutase, vol. 2, pp. 83-125. Edited by L. W. Oberley. Boca Raton, FL: CRC Press.

Gaulthier, G., Lafay, B., Ruimy, R., Breittmayer, V., Nicolas, J. L., Gauthier, M. \& Christen, R. (1995). Small subunit rRNA sequences and whole DNA relatedness concur for the reassignment of Pasteurella piscicida (Snieszko et al.) Janssen and Surgalla to the genus Photobacterium as Photobacterium damselae subsp. piscicida comb. nov. Int J Syst Bacteriol 45, 139-144.

Graham, S., Jeffries, A. H. \& Secombes, C. J. (1988). A novel assay to detect macrophage bactericidal activity in fish: factors influencing the killing of Aeromonas salmonicida. J Fish Dis 11, 389-396.

Gregory, E. M., Yost, F. J. \& Fridovich, I. (1973). Superoxide dismutases of Escherichia coli: intracellular location and functions. J Bacteriol 155, 987-991.

Halliwell, B. (1981). Free radicals, oxygen toxicity and ageing. In Age Pigments, pp. 1-62. Edited by R. S. Sohal. Amsterdam: Elsevier.

Halliwell, B. \& Gutteridge, J. M. C. (1984). Oxygen toxicity, oxygen radicals, transition metals and disease. Biochem $J 219$, $1-14$.

Hampton, M. B., Kettle, C. J. \& Winterbourn, C. C. (1996). Involvement of superoxide and myeloperoxidase in oxygen- 
dependent killing of Staphylococcus aureus by neutrophils. Infect Immun 64, 3512-3517.

Hardie, L. J., Ellis, A. E. \& Secombes, C. J. (1996). In vitro activation of rainbow trout macrophages stimulates inhibition of Renibacterium salmoninarum growth concomitant with augmented generation of respiratory burst products. Dis Aquat Org 25, $175-183$

Hawke, J. P., Plakas, S. M., Minton, R. V., McPhearson, R. M., Snider, T. G. \& Guarino, A. M. (1987). Fish pasteurellosis of cultured striped bass (Morone saxatilis) in coastal Alabama. Aquaculture 65, 193-204.

Hedrick, J. L. \& Smith, A. J. (1968). Size and charge isomer separation and estimation of molecular weights of proteins by disc gel electrophoresis. Arch Biochem Biophys 126, 155-164.

Imlay, J. A. \& Fridovich, I. (1991). Assay of metabolic superoxide production in Escherichia coli. J Biol Sci 266, 6957-6965.

Imlay, J. A. \& Linn, S. (1988). DNA damage and oxygen radical toxicity. Science 240, 1302-1309.

Karczewski, J. M., Sharp, G. J. E. \& Secombes, C. J. (1991). Susceptibility of strains of Aeromonas salmonicida to killing by cell-free generated superoxide anion. J Fish Dis 14, 367-373.

Keele, B. B., Jr, McCord, J. M. \& Fridovich, I. (1970). Superoxide dismutase from Escherichia coli $\mathrm{B}$ : A new manganese containing enzyme. J Biol Chem 245, 6176-6181.

Keyer, K., Gort, A. S. \& Imlay, J. A. (1995). Superoxide and the production of oxidative DNA damage. $J$ Bacteriol 177, $6782-6790$.

Klotz, M. G. \& Hutcheson, S. W. (1992). Multiple periplasmic catalases in pathogenic strains of Pseudomonas syringae. Appl Environ Microbiol 58, 2468-2473.

Kubota, S., Kimura, M. \& Egusa, S. (1970). Studies on bacterial tuberculoidosis in cultured yellowtail. I. Symptomatology and histopathology. Fish Pathol 4, 111-118.

McCord, J. M. \& Fridovich, I. (1969). Superoxide dismutase: an enzymatic function for erythrocuprein. $J$ Biol Chem 244, 6049-6055.

Magariños, B., Santos, Y., Romalde, J. L., Rivas, C., Barja, J. L. \& Toranzo, A. E. (1992). Pathogenic activities of live cells and extracellular products of the fish pathogen Pasteurella piscicida. $J$ Gen Microbiol 138, 2491-2498.

Magariños, B., Romalde, J. L., Lemos, M. L., Barja, J. L. \& Toranzo, A. E. (1994). Iron uptake by Pasteurella piscicida and its role in pathogenicity for fish. Appl Environ Microbiol 60, 2990-2998.

Magarińos, B., Romalde, J. L., Noya, M., Barja, J. L. \& Toranzo, A. E. (1996). Adherence and invasive capacities of the fish pathogen Pasteurella piscicida. FEMS Microbiol Lett 138, 29-34.

Mandell, G. L. (1975). Catalase, superoxide dismutase, and virulence of Staphylococcus aureus. In vitro and in vivo studies with emphasis on staphylococcal-leukocyte interaction. J Clin Invest 55, 561-566.

Nelson, J. S., Kawahara, E., Kawai, K. \& Kusuda, R. (1981). Macrophage infiltration in pseudotuberculosis of yellowtail, Seriola quinqueradiata. Bull Mar Sci Fish Kochi Univ 11, 17-22.

Noya, M., Magarińos, B. \& Lamas, J. (1995a). Interactions between peritoneal exudate cells (PECs) of gilthead seabream (Sparus aurata) and Pasteurella piscicida. A morphological study. Aquaculture 131, 11-21.
Noya, M., Magariños, B., Toranzo, A. E. \& Lamas, J. (1995b). Sequential pathology of experimental pasteurellosis in gilthead seabream Sparus aurata. A light- and electron-microscopic study. Dis Aquat Org 21, 177-186.

Pardee, A. B. \& Watanabe, K. (1968). Location of sulfate binding protein in Salmonella typhimurium. J Bacteriol 96, 1049-1054.

Randall, L. L. \& Hardy, S. J. S. (1989). Unity in function in the absence of consensus in sequence: Role of leader peptides in export. Science 243, 1156-1159.

St John, G. \& Steinman, H. M. (1996). Periplasmic copper-zinc superoxide dismutase of Legionella pneumophila: role in stationary-phase survival. $J$ Bacteriol 178, 1578-1584.

Short, K. A. \& Blakemore, R. P. (1989). Periplasmic superoxide dismutases in Aquaspirillum magnetotacticum. Arch Microbiol 152, 342-346.

Skarmeta, A. M., Bandín, I., Santos, Y. \& Toranzo, A. E. (1995). In vitro killing of Pasteurella piscicida by fish macrophages. Dis Aquat Org 23, 51-57.

Smith, D. K. \& Winkler, H. H. (1979). Separation of inner and outer membranes of Rickettsia prowazeki and characterization of their polypeptide compositions. J Bacteriol 137, 963-971.

Sniezsko, S. F., Bullock, G. L., Hollis, E. \& Boono, J. G. (1964). Pasteurella spp. from an epizootic of white perch (Roccus americanus) in Chaesapeake Bay tidewater areas. J Bacteriol 88, 1814-1815.

Stabel, T. J., Sha, Z. \& Mayfield, J. E. (1994). Periplasmic location of Brucella abortus $\mathrm{Cu} / \mathrm{Zn}$ superoxide dismutase. Vet Microbiol 38, 307-314.

Tardat, B. \& Touati, D. (1991). Two global regulators repress the anaerobic expression of MnSOD in E. coli: Fur (ferric uptake regulation) and Arc (aerobic respiration control). Mol Microbiol $5,455-465$.

Toranzo, A. E., Barreiro, S., Casal, J. F., Figueras, A., Magariños, B. \& Barja, J. L. (1991). Pasteurellosis in cultured seabream (Sparus aurata) : first report in Spain. Aquaculture 99, 1-15.

Tsolis, R. M., Baumler, A.J. \& Heffron, F. (1995). Role of Salmonella typhimurium Mn-superoxide dismutase (SodA) in protection against early killing by $\mathrm{J} 774$ macrophages. Infect Immun 63, 1739-1744.

Ueki, N., Kayano, Y. \& Muroga, K. (1990). Pasteurella piscicida in juvenile red grouper. Fish Pathol 25, 43-44.

Welch, D. F., Sword, C. P., Brehm, S. \& Dusanic, D. (1979). Relationship between superoxide dismutase and pathogenic mechanisms of Listeria monocytogenes. Infect Immun 23, 863-872.

Winterbourn, C. C. (1979). Comparison of superoxide with other reducing agents in production of hydroxyl radicals. Biochem $J$ $182,625-628$.

Woodbury, W., Spencer, A. K. \& Stahmann, M. A. (1971). An improved procedure using ferricyanide for detecting catalase isozymes. Anal Biochem 44, 301-305.

Worthington Enzyme Manual (1993). Freehold, NJ; Worthington Biochemical Corp.

Yost, F. J., Jr \& Fridovich, I. (1973). An iron-containing superoxide dismutase from Escherichia coli. J Biol Chem 248, 4905-4908.

Received 22 June 1998; revised 18 October 1998; accepted 5 November 1998. 